\title{
Heteroglossia: Bakhtinian Dialogism within a Play's Monologue
}

\author{
Amir Abbas Moslemi, Shiva Hemmati \\ E-mail address: a.a.moslemi@gmail.com
}

Keywords: language; speech; Irish Drama; Russian Formalism; Joyce; O'Halloran; Bakhtin; theory of novel; dialogism; intertextuality; heteroglossia; polyphony; monologue; stratification

\begin{abstract}
This study tries to expand the richness of Bakhtin's theory of novel by showing the reader that its thorough features could be traced back in a play rather than a novel, considering it more than what is usually the basis of "historical poetics" mainly in the form of a novel accentuating the constitution of a social ideology besides an individual one while gesturing dialogically in the interaction between representation in its textual form and particularities of its proper probable forces in their socio-historical stratifications within notions such as dialogism, intertextuality, heteroglossia and polyphony. To do so a successful Irish play of exuberance is invited to be served by a thinker from the past Soviet. Since the references are written in an artistic language, a language near to a poetic one tries to tinker rationality to irrationality. In the light of O'Halloran's eccentric nostalgia which tries to handle a play all in all monologically from the voice of just a single character, one may seem to be listening to the symphony of Bakhtin's polyphonic heteroglossia stratified within the architectonics of both authors' interillumination.
\end{abstract}

\section{HOLD}

\author{
"I live in a world of others' words". \\ (Bakhtin, Problems of Dostoevsky's Poetics)
}

Seeping down into the utterly subjective narration of Red, in The Head of Red O'Brien or The Last Monologue by Mark O'Halloran, who is seated on a bed in a hospital with a projector throwing scenes of submarines, water and oranges on the wall, reveals a traumatic discourse not easily able to be literalized by language. His replay of the Hold scene of a movie after his taxonomical opening of the play about his clinical conditions makes the audience look for notions far much more than homophobia or obsession and the like.

Where does Red live? "Hold....hold....hold.....hold" (1).

Tom Clancy's best-selling novel, which was published in 1984, creates Marko Ramius (Connery) with an accent of Scots repeating this word throughO'Halloran's play while Red is literally plummeting to the bottom of his nuptial life compared to the possibility of the submarine's simultaneous disastrous explosion under the oceanic gigantic waves, as the Russian navy versus American fleet are silently trying to shoot their way out by nothing but missiles, like a knife stabbing the head of Red, who is Mary Motorhead's husband, while she is distinguished to be the best of shooters, when either the reader is holding the paper in his hand or the watcher is watching the performance, this hold is held now and is asked to be held and is ordered to be held and there is for sure a manifold of other holds as if they are kept in the hold of a ship in the addressee's stock of words which hence keeps holding this hold-process back to what Bakhtin calls heteroglossia or other's word: "Any understanding of live speech, a live utterance, is inherently responsive... any utterance is a link in the chain of communication" (Speech Genres, 68, 84).

Bakhtin's marking of a word or an utterance by addressivity and answerability clarifies a different attitude towards defining a word. Not only does a word exist by itself, but also it lives a living as live as the context in which it is located so that its context should be lived among other contexts, creating a live context, too. Context within another context cannot be anything other than history within history, culture within another culture, place within another place, or a community 
within another community. "The word lives, as it were, on the boundary between its own context and another, alien, context" (Bakhtin, The Dialogic Imagination 284).

Red's repetition suggests concentration. Starting from the author himself, the one who should hold his state to keep the privilege of responsibility of his writing state, the reader in the reading state and the watcher in the watching one, under no circumstances, suggests to be a lack of focus. An eradication towards the lack of concentration asks for a repetition of a command to hold. Red does not select the word hold by chance. His life style is not far away from the style which Sean keeps on performing now and then. "He (Sean) is probably the best friend I (Red) ever had" (8).

Considering stylization of the character, from its apparent physical features to its complex characterization, the closeness of Red's style in comparison to Sean's is portrayed wonderfully by some intelligently chosen features simple but important, like being bald. The first thing which is done after introducing Connery is to make certain intimate relationships between the protagonist and his hero to establish a proximity in everything even their hair-style. Life-style, hair-style and so forth lead to the very atmosphere in which a writer probably selects a word Bakhtinianly.

When we select words in the process of constructing an utterance, we by no means always take them from the system of language in their neutral, dictionary form. We usually take them from other utterances, and mainly from utterances that are kindred to ours in genre, that is, in theme, composition, or style (Speech Genres 87).

It is not merely the style of a writer in his writing composition which is the point here. Hold in Bakhtin's view cannot be selected by chance while Red's initiative use of the word in the very first page of the play approves of our explicit objective.

You see what I was saying wasn't forced or compulsive like they thought. It was chosen. I was imagining he was here and saying what he'd have said. Repeating it over and over again. Hold ....hold ....hold.....hold (1).

Hold in Bakhtin's view is mixed with heteroglossia which is other's word or speech. Works of art, novels, philosophical arguments or other kinds of complex cultural discourses even scientific descriptions are made of a web of other's speech. This state of being many-voiced is called the polyphonic feature of speech which necessarily causes discourse to be of many styles and assumptions or references of other's but not the speakers 'own'. Bakhtin believes that while there is any expression, either a complex cultural one or a dialog in a live conversation, it requires a network of statements and responses which they themselves require new statements with a presupposition of earlier statements and an anticipation of future responses generally creating a dialogue.

The word in living conversation is directly, blatantly, oriented toward a future answer-word: it provokes an answer, anticipates it and structures itself in the answer's direction. Forming itself in an atmosphere of the already spoken, the word is at the same time determined by that which has not yet been said but which is needed and in fact anticipated by the answering word. Such is the situation with any living dialogue. The orientation towards an answer is open, blatant and concrete (Bakhtin, The Dialogic Imagination 279).

Hence, an unfinalizability of a dialogic expression, always incomplete with a production of future oriented web of responsesis present, which generates meaning to be always closed with an orientation towards the future.

Nothing conclusive has yet taken place in the world, the ultimate word of the world and about the world has not yet been spoken, the world is open and free, and everything is still in the future and will always be in the future (Bakhtin, "Problems" 166).

Now hold is living from Clancy to Red and further. A form of lifestyle of hold is going to be responded due to its answerability until this word becomes the earworm of a lost speaker who is proteously shape-shifting from O'Halloran to Marko to Clancy and Sean or from this nation to that 
while a lot more and more are to be addressed in their addressivity, then it goes on and on till intersubjectivity is introduced.

\section{A NOVEL OR A PLAY}

Red October is named after the revolution of 1917, a new heavy-class Soviet nuclear vessel commanded by Marko Ramius, able to sail totally undetectable to sonar owing to its feature called caterpillar drive. The Hunt for Red October is a 1990 thriller film based on Tom Clancy's novel of the same name. The movie is new to town and is the favorite of Red O'Brien whose hero is Connery, cooler than before, staring as the head of Red October. Both American and Russian fleets try to sink Red October while its captain is heading towards America to defect. He has jettisoned all his fear to bury the unique sailing vehicle as his powerful ideological direction is emancipating itself exactly on his wife's first burial anniversary. While everybody has made his own decisions and is insisting to go his own way Red asks Mary to go to cinema with him to watch how a man is starting a war calmly to compensate all his government's guilty history in his 40 years of truthful labor in communist Soviet Union. Bakhtin who was never a member of the Communist Party, established a school of thought to transcend his surroundings by notions such as dialogism, polyphony and heteroglossia, non-conformist to Stalin, was finally exiled to Kazakhstan.

Although The Head of O'Brien or The Last Monologue is a play written for performance, the features into which Bakhtin's unity of novel are divided to, are traceable in. The first feature is the direct authorial narration which can be distinguished if only we consider the broader view of the nature of language as dialogic and as comprised of heteroglossia. A domestic accident's victim, through the mouth of a quasi-vivisepulture, underneath a load of detritus, under the tombs, beneath the ruins of a life, starts to talk. A character who is as the loneliest creature ever created, is by himself alone in a room, a hospital room, a grave one might call it, narrating his graveyard.

Like dead villages in my head. Forgotten pit stops on the road from catastrophe back to her, back to myself. Sometimes, during my recovery and reconstruction, by way of a sedative, a meditation, I'd recite the list of my ailments to myself. I'd always end up pissing myself laughing. That it should come to this (1).

O'Halloran opens the play in medias res. "That it should come to this" transfixes a nostalgic rather than an instance of redeeming at least much sooner than the reader is "waiting, awaiting the fullness of their times. (Joyce 49). It is not a simple sentence. It is the very echo of Saint Ambrose which Joyce prefers in its original language: "diebus ac noctibus iniurias patiens ingemiscit" (Joyce 49) ${ }^{1}$. One ought to read the whole play and still won't be aware of the core of the idea. The sentence is written so cunningly that Joyce doesn't hesitate to make it topnotch by writing: "To no end gathered: vainly then released, forth flowing, wending back: loom of the moon" (Joyce 49). Joyce has introduced these waves a few pages before he invites you to behold them as "curling, unfurling many crests, every ninth, breaking, plashing, from far, from farther out, waves and waves" (Joyce 46). Now what O'Halloran does is to leave the audience alone on the summit of one of these tides, rafting and surfing from this language to that language. The opening paragraph of the play starts with aphonia, the third one with Echolania while just here in between we have the second one as a mirage of post-linguistic architechtonics. Scattered words, fragmented syntax, unembellished, naïve and innocent casual speech and suddenly "wending back" to the most scientific terms that may even be far-fetched for a doctor among the audience. The reader is left alone with this extra-artistic speech that can be scientific, philosophical, or a moral statement which is Bakhtin's second feature.

Anablepsy, Aprenia, Ophthalmoplegia, Orexia, Blephorospasm, micrographia, Echolalia.....(1)

\footnotetext{
1 "Night and day he patiently groaned forth his wrongs" (Saint Ambrose).
} 
Red doesn't claim this language to be his. To take it in more comfortably, he redefines it. This patient's definition is much more exact and precise than those of the doctors.

Echolalia. Now I think that one was a misdiagnosis. Echolalia is the forced repetition of someone's words over and over again. Sometimes coupled with catalepsy, the forced repetition or echoing of postures, but I showed no signs of that. You see what I was saying wasn't forced or compulsive like they thought. It was chosen. I was imagining he was here and saying what he'd have said. Repeating it over and over again (1).

Taking this possession or dispossession of language for granted, who does "he" refer to? The reader is not familiar with its referent yet. Let's compare "repetition of someone's words over and over again" plus "he" with Kristeva's reading of Bakhtin:

In Bakhtin's work, these two axes, which he calls dialogue and

ambivalence, are not clearly distinguished. Yet, what appears as a lack

ofrigour is in fact an insight first introduced into literary theory by

Bakhtin: any text is constructed as a mosaic of quotations; any text is

the absorption and transformation of another (Kristeva 37).

What kristeva believes to be "reading a poetic language at least double" (Kristeva 37) is hence the swift juxtaposition of multiple narrations with the direct authorial one initiating the work as if, from the very beginning the whole traits of Bakhtinian novel is unpacked at once in front of the reader so that he or she won't be searching for more instances. Reality, solid and vivid is represented even the very moment the play starts.

The third one is an everyday stylized speech. Within that language, we advise each other. Red, take us in, inner than before, when he utters: "And so this is the advice I give to anyone poorly -Take pride in your sickness. Own it. It is as unique and special as you are" (3). Within the same language, we ask for each other's ideas. He is not even asked though.

My arrival in hospital this last time was some hoopla. Not like before when I was just a no-one left on a trolley with a few broken fingers and a bit of concussion. Maybe in overnight for observations. Whose observations? I wasn't asked for mine ever (4).

There is also the possibility of curses in everyday talk. "I should have read the warning signs I suppose. We even tried splitting up once. A ferocious row outside a chipper during which she called me a useless 5' stack of shite and stormed off. We didn't see each other for two weeks and - (5) and "she broke her shite" (5), or "if she did she sure as shite never let on" (8) and "Here, horse, read that and tell me what you think" (13).

Another feature is the use of letters or diaries which are a part of semi-literary discourse. "Happy Christmas from Pat and Nancy" and also, "Ye're nothing but Tinkers" (6). The last one is the speech of characters which is individualized only to themselves. "Anyways, bonkers the lot of them" (3). "Always being less then they tried to describe, always falling short, never being able to make full sense, always undervaluing what was described" (17). Where "hurt" should be hurts in "I think that's what hurt the most" (4) is not the only place where it is played with third person singular $s$ or plural $s$ to cripple the linguistic frame of the language resulting in a more individualized one to be suited for Red. Taking the commonality of $\mathrm{s}$ at the end of hurts for granted which could be remained from Middle English, one may try to distinguish "then" from "than" in this instance. Consider s at the end of "says" and "loves" in this quotation: "Well - says I hauling myself up to my full shambles - As a man with Dual Circum Orbital Haematoma, I think I'm entitled to a few emotional moments with the one that I loves" (3).

Bakhtin believes that novel can be "defined as a diversity of social speech types (sometimes even diversity of languages) and a diversity of individual voices, artistically organized" (The Dialogic Imagination 262) and that language is "stratified" in its own nature with another stratification within its own stratified system demanding various languages to be suitable for various types of people with various voices. Red O'Brien has his own language, his own "anyways" as his doctors who have their own language which Red is hopeless to communicate with. He finds 
Clancy's language communicable to his own so appropriately that he spends his every night at cinema to be in an atmosphere in which a dialogical transaction of the very language is taking place.

Bakhtin believes that "in the creative consciousness of people who write novels", there happens a process which on the contrary to poetry, not only carries the whole "ttaste" of a profession, a genre, a tendency, a party, a particular work, a particular person, a generation, an age group, the day and hour", but also the "dialectological unity of the shared literary language" which is merely a part of its "social stratification" (Rivkin and Ryan 675-6) is also transferred.

Red is reciting Marko at home, besides following his strategies. Marko turns towards the annihilating torpedo to make it get passed by, which is of a so lovely idea in Red's mind that he turns towards Mary's torpedo when she groans to watch the movie with him. How? He just heads to Mary with the novel of the movie in his hand. Mary who doesn't have any time to arm herself throws the book into fire. Red believes that the Captain paid a man as casualty but not the book as his own, possibly since he believes that books are nothing but "dry rot" (8).

The language is not lost in between. This is the very language of a husband and wife. Bakhtin continues:

The prose writer as a novelist does not strip away the intentions of others from the heteroglot language of his works, he does not violate those socio-ideological cultural horizons (big and little worlds) that open up behind heteroglot languages - rather, he welcomes them into his work (Rivkin and Ryan 678).

\section{MYSTICISM OR COINCIDENCE}

Marko's order to let his crew carry on singing, bypasses Bakhtin's phrase-"language and the world of song" (Rivkin and Ryan 678) specially when heard by "Jonesy", a sonar technician on the USS Dallas who other than being called Beethoven on computer, takes side against his commander to correct him in distinguishing Paganini from Pavarotti. He hears a singing of a song, under millions tons of water, not in his own submarine, but from the other's.

Red, characterized by different sorts of linguistic oriented ailments has no problem remembering the very song he needs to recall: "Do You Think I'm Sexy" by Rod Stewart. The reason that "Ya" is changed to "You" can be a matter of the character's individualized language.

The Russians call Marko Vilnius Nastavnic which means the Vilnius Schoolmaster. Is it only a coincidence that Bakhtin was actually grown up in Vilnius? Alone, in his room, he has not issued any order for seven hours. One of his men who doesn't believe in him calls him a schoolboy. Schoolboy or schoolmaster, what is he doing? Seven is dear to the mystic mind (Joyce, Ulysses 9.22).

Is he mystic? What does he murmur under his lips before his sporadic sudden turning towards right, called Crazy Ivan? Why right? He is aware of the stratification which lies beneath Einstein's words, the ancient Hindu text, but he says he keeps the book for sentimental value. His last words in the final scene are a quotation from Christopher Columbus: "And the sea will grant each man new hope as sleep brings dreams of home" (The Hunt for Red October).

Red is listening to him every night. Red is going to cinema every night to be with him, to interpret his poetic language as Bakhtin calls it. Is there anybody else who can interpret what he says? Not in the real world. He should be within this novelistic world. He should be of Clancy's nature. He should not be from any other nature other than of this novelistic language. John Patrick "Jack Rayan" is the very fictionary character we are talking about. He is a novelist, a writer, an analyst who is able to smile lovingly at his girl's communication with Stanley, a teddy bear lovingly. O'Halloran's artistic language like Clancy's, differentiates the language of politicians, doctors, seamen, Pavarotti, Paganini, KGB, English, Russian, accents, generals, academics, ambassadors, the baby girl and of the teddy bear, the language of the algorithmic processing systems and hundreds of more associative ones which Red is potentially capable to comprehend while a knife is plunged into his head. When he finds himself unable to transfer all these stratifications which Bakhtin names "socio-ideological cultural horizons' (Rivkin and Ryan 678), 
O'Halloran invites us to watch Red's movement artistically in a trance accompanying with light, images and music, which open up a language that only an adroit playwright is able to take advantage of; a novel-oriented language.

\section{CONCLUSION}

Categorization of a work of art was the last thing Bakhtin ever wanted to do. Encompassing greater intentions, he managed to form a general theory called the theory of novel. Applying his theory so narrow-mindedly to a well-written Irish play revealed that, an example might be enough to ask for an afterthought about the classification of some works of art. A good playwright has got the ability to create such spectrum overlapped by the features of two distinct classes. If one associates his own expansive understanding of Bakhtin's ideas, the sine-qua-non of novel, his concept of dialogism can be traced in even a play with an adequate nice amount of depth in style and poetics. Dialogic presence portrayed in these pages showed that The Last Monologue or The Head of Red O'Brien holds Bakhtin's theory of novel within itself while in fact it is a play written for the stage to be played.

Hence, to call it a play or a novel, let's “HOLD”.

\section{References}

[1] Bakhtin, Mikhail. Problems of Dostoevsky's Poetics. Ed.Caryl Emerson. Minneapolis, MN:

a. University of Minnesota Press, 1984.

b. Speech Genres and Other Late Essays. Eds. Emerson, Caryl and Michael Holquist. Trans.

c. Vern W. McGee. Austin, TX: University of Texas Press, 1986.

d. The Dialogic Imagination: Four Essays. Ed. Holquist. Michael, Trans. Caryl Emerson and Michael Holquist. Austin: University of Texas Press, 1981

[2] Clancy, Tom. The Hunt for Red October, Berkley Books, 1985.

[3] Joyce, James. Ulysses, The 1922 Text, with an introduction and notes by Jeri Johnson, Oxford University Press, 1993.

[4] O'Halloran, Mark. The Head of Red O'Brien; or, The Last Monologue. Dublin. 2001

[5] Rivkin, Julie and Michael Ryan. Literary theory, an anthology. Eds. Julie Rivkin and Michael Ryan. $2^{\text {nd }}$ ed. Print.

[6] Kristeva, Julia. Kristeva Reader The. Ed.Toril Moi. New York: Columbia University Press, 1986. 